\title{
HUBUNGAN ANTARA ETOS KERJA, MOTIVASI, SIKAP INOVATIF DAN \\ PRODUKTIVITAS USAHATANI \\ (Studi Kasus Pada Usahatani Padi Sawah di Kecamatan Tumpaan \\ Kabupaten Minahasa Selatan)
}

\author{
Vicky R.B. Moniaga \\ Jelly Memah \\ Christy Rondonuwu
}

\begin{abstract}
This study aims to (a) describe these three psychological factors and productivity of rice farming, and (b) to study whether there is a significant relationship between these psychological factors (work ethic, achievement motivation and innovative attitude) with farm productivity. Based on the analysis of descriptions of the main variables of the study, then through the method of "Likert's Summated Ratings" in the measurement of psychological variables in the know that the three psychological variables were in levels of "High" (from 5 measurement scales: from very low to very high). relatively variable work ethic scores 79.4 percent, 71.1 percent motivation, and innovative attitude of 78.4 percent. While for the variable productivity of rice varies from 1163.64 to $3030.30 \mathrm{~kg} / \mathrm{ha}$ with an average of $2042.30 \mathrm{~kg} / \mathrm{ha}$ of rice equivalent.

In the method of Pearson correlation analysis then known that the variable work ethic and innovative attitude variables are very significant berhubingan with rice productivity, which in this case addressed by the magnitude of correlation coefficient ( $r=0.67, p=0.00)$ for variable ethos employment and productivity, and ( $r=0.696, p=0.00)$ for variable innovative attitude and productivity. this means that the size of the productivity of paddy rice farming posiyif no relationship with work ethic and innovative attitude of the farmers. while the motivation is not there a significant relationship with lowland rice farming productivity variable ( $r=0.21, p=0.27$ ). This means that farmers in increasing their business productivity is not driven by emotional intelligence but more driven olek because of necessity (there is no other choice) in developing rice farming. so that the size of the productivity is not determined by the high and low motivation of farmers.
\end{abstract}

Keywords: Work ethic, achievement motivation, innovative attitude, farm productivity

\section{PENDAHULUAN}

\section{Latar Belakang}

Kebijakan dan strategi pembangunan pertanian di Sulawesi Utara merupakan perpaduan antara kebijakan pembangunan pertanian nasional dan perencanaan pembangunan pertanian daerah. Secara umum kebijakan pembangunan daerah Provinsi Sulawesi Utara didasarkan atas Dokumen perencanaan pembangunan daerah Provinsi Sulawesi Utara berupa Rencana Pembangunan Jangka Menengah Daerah (RPJMD) Provinsi Sulawesi Utara Tahun 2005-2010 dan Grand Design Revitalisasi Pertanian Provinsi Sulawesi Utara. Dari dua dokumen tersebut secara tegas dan jelas mengamanatkan komitmen pemerintah Provinsi Sulawesi Utara dalam membangun Sektor Pertanian dan Peternakan secara terencana, terpadu dan menyeluruh dengan tujuan untuk :

a) Meningkatkan kesejahteraan masyarakat,

b) Menurunkan kemiskinan dan pengangguran,

c) Meningkatkan produksi dan mutu hasil pertanian,

d) Meningkatkan akses petani, ke sentra produksi, sumber permodalan, pengolahan dan pemasaran dan sumber teknologi (Dinas Pertanian \& Peternakan Prov. Sulut, 2009)

Program Revitalisasi Pertanian merupakan kebijakan publik yang ditetapkan pemerintah provinsi Sulawesi Utara dalam rangka mengatasi 
masalah: a). Kemiskinan, b). Pengangguran, $c$ ), Ketahanan Pangan, d) Pelestarian Lingkungan Hidup, untuk mencapai peningkatan kesejahteraan masyarakat, terutama petani dan peternak di pedesaan. Untuk mempercepat penanggulangan masalah ketahanan pangan khususnya, pemerintah daerah Provinsi Sulawesi Utara juga telah mencanangkan suatu gerakan swasembada beras yang ditargetkan tercapai pada tahun 2010 ini. Untuk itu, setiap daerah (kabupaten/kota) berupaya mendukung program peningkatan pangan, khususnya beras melalui berbagai pendekatan dan strategi pembangunan. Meskipun berbagai kebijakan, strategi dan program telah digalakkan oleh pemerintah selama ini, tetapi nampaknya belum dapat memberikan perubahan yang berarti terhadap kinerja pembangunan pertanian. Khususnya untuk komoditas padi sebagai sumber karbohidrat utama bahan pangan penduduk masih dijumpai banyak masalah, antara lain masih rendahnya produksi akibat rendahnya tingkat produktivitas. Tahun 2009 ditargetkan produksi padi di Sulawesi Utara sebesar 546.825 ton tetapi realisasinya hanya 461.450 ton atau sekitar 84 persen dan produktivitas padi sawah baru sekitar 5 ton per hektar (BPS Sulut, 2008), sementara untuk mencapai swasembada beras, produktivitasnya sekitar 6 ton per hektar, dengan asumsi luas lahan dan kondisi lainnya tetap (Dinas Pertanian dan Peternakan Sulut, 2009). Masalah lainnya adalah semakin menyusutnya lahan sawah akibat peralihan fungsi (menjadi lahan pemukiman, industri, penggembalaan ternak, dan lainnya), sementara bangunan irigasi untuk pengairan sawah tidak ada peningkatan; semakin meningkatnya jumlah penduduk yang akan mendorong meningkatnya permintaan terhadap beras; adanya kendala dalam distribusi sarana produksi pertanian (terutama pupuk dan benih); serta lemahnya kelembagaan petani.

Tabel 1. Luas Tanam. Luas Panen dan Produksi Padi Sawah di Kabupaten Minahasa Selatan

\begin{tabular}{lcccc}
\hline No. Kecamatan & $\begin{array}{c}\text { Luas Tanam } \\
(\mathrm{Ha})\end{array}$ & $\begin{array}{c}\text { Luas Panen } \\
(\mathrm{Ha})\end{array}$ & $\begin{array}{c}\text { Produksi } \\
(\text { Ton })\end{array}$ & $\begin{array}{c}\text { Produktivitas } \\
\text { (Ton/Ha) }\end{array}$ \\
\hline$(1) \quad(3)$ & $(4)$ & $(5)$ & $(6)$ \\
\hline 1. Modoinding & 23 & 33 & 158,2 & 4,79 \\
2. Tompaso Baru & 2083 & 2087 & 0034,3 & 4,81 \\
3. Maesaan & 1983 & 2018 & 9700,5 & 4,81 \\
4. Ranoyapo & 287 & 2321 & 1157,0 & 4,81 \\
5. Motoling & 240 & 226 & 1084,3 & 4,80 \\
6. Kumelembuai & 39 & 40 & 191,2 & 4,78 \\
7. Motoling Barat & $*)$ & $*)$ & $*)$ & $*)$ \\
8. Motoling Timur & $*)$ & $*)$ & $*)$ & $*)$ \\
9. Sinonsayang & 538 & 557 & 2674,7 & 4,80 \\
10. Tenga & 1729 & 800 & 8668,8 & 4,82 \\
11. Amurang & 17 & 22 & 105,4 & 4,79 \\
12. Amurang Barat & 178 & 183 & 875,7 & 4,79 \\
13. Amurang Timur & 315 & 303 & 452,9 & 4,80 \\
14. Tareran & 719 & 567 & 721,0 & 4,80 \\
15. Sulta & $*)$ & $*)$ & $*)$ & $*)$ \\
16. Tumpaan & $\mathbf{8 5 3}$ & $\mathbf{7 7 1}$ & $\mathbf{7 0 4 , 7}$ & $\mathbf{4 , 8 1}$ \\
17. Tatapaan & 879 & 763 & 663,2 & 4,80 \\
\hline Jumlah/Total & 11883 & 11691 & 56191,9 & 4,81 \\
\hline Sumber : Dinas Pertanian dan Peternakan Kabupaten Minahasa Selatan $(2010)$ & & &
\end{tabular}

Sumber : Dinas Pertanian dan Peternakan Kabupaten Minahasa Selatan (2010) 
Dari fakta di atas dapat menjelaskan bahwa keberhasilan pembangunan pertanian, khususnya peningkatan produksi dan produktivitas padi sawah tidak saja teretak pada peran pemerintah melalui rumusan kebijakan dan strategi pembangunannya serta jajaran operasionalnya (para petugas penyuluhan pertanian); dan tidak pula tergantung semata pada penggunaan teknologi produksi yang teredia. Tetapi keberhasilan pembangunan pertanian sangat tergantung pada peran serta petani. Menurut Tuyuwale (2008), untuk mengoptimalkan peran serta petani ada dua aspek yang berperan, pertama, aspek keperilakuan (behavioral) yang meliputi pengetahuan, keterampilan dan sikap (afektif); dan kedua, aspek kepribadian (personality) yang meliputi etos kerja, motivasi dan sikap mental (attitude).

Menurut Iskandar (2002), untuk meningkatkan produktivitas petani khususnya dalam meningkatkan produksi beras maka diperlukan tidak hanya dari peningkatan produktivitas melalui pengelolaan lahan pertanian dan sarana produksi seperti penggunaan pupuk, penggunaan varietas baru dan perluasan areal irigasi seperti telah diuraikan sebelumnya, akan tetapi perlu dicari upaya lain untuk meningkatkan produksi pertanian yaitu melalui peningkatan managemen usaha para petani itu sendiri yang menyangkut faktor-faktor psikologis dari petani seperti, etos kerja, motivasi keberhasilan dan sikap inovatif mereka dalam bidang pertanian khususnya usahatani padi sawah.

Sehubungan dengan fenomena di atas maka menarik untuk diteliti aspek psikologis petani tersebut yang meliputi etos kerja, motivasi kerja (achievement motivation) dan sikap inovatif petani dikaitkan dengan produktivitas usahatani padi sawah dengan mengambil kasus di salah satu daerah sentra produksi padi sawah di daerah Kabupaten Minahasa Selatan, yaitu Kecamatan Tumpaan. Mengapa di Kecamatan Tumpaan? Seperti diketahui bahwa di Kabupaten Minahasa Selatan ada upaya untuk memacu pembangunan pertanian melalui pengembangan kawasan cepat tumbuh "TURANGA" (Tumpaan, Amurang dan Tenga). Kawasan pengembangan ini memiliki luas panen padi sawah sebesar 3.842 hektar dengan tingkat produktivitas di antara 4,7 - 4,8 ton per hektar (BPS Minsel, 2008) dan Kecamatan Tumpaan sendiri memiliki luas tanam dan luas panen berturut-turut sebesar 853 ha dan 771 ha dengan jumlah produksi pada tahun 2007 sebesar 704,7 ton dan produktivitas 4,81 ton/ha.

\section{Perumusan Masalah}

Berdasarkan latarbelakang diatas maka masalah yang akan dijawab dalam penelitian ini dapat dirumuskan sebagai berikut:

a. Seberapa tinggi etos kerja, motivasi kerja dan sikap inovatif petani dalam hubungan dengan pengembangan usahataninya serta seberapa tinggi produktivitas usahatani padi sawah yang digarap petani?;

b. Apakah terdapat hubungan antara etos kerja petani dengan produktivitas usahatani padi sawah?

c. Apakah terdapat hubungan antara motivasi kerja petani dengan produktivitas usahatani padi sawah?

d. Apakah terdapat hubungan antara sikap inovatif petani dengan produktivitas usahatani padi sawah?

e. Dan apakah ada faktor-faktor lain yang berhubungan dengan produktivitas usahatani padi sawah?

\section{Tujuan dan Manfaat Penelitian}

Berdasarkan rumusan masalah penelitian yang dikemukakan di atas, maka tujuan penelitian ini dapat dirumuskan sebagai berikut:

a. Untuk mendeskripsikan etos kerja petani, motivasi kerja petani dan sikap inovatif petani serta produktivitas petani (dalam hal ini produktivitas usahatani padi sawah yang digarap petani);

b. Untuk mengetahui apakah terdapat hubungan yang signifikan antara etos kerja petani dan produktivitas usahatani padi sawah; 
c. Untuk mengetahui apakah terdapat hubungan yang signifikan antara motivasi berprestasi dan produktivitas usahatani padi sawah; dan

d. Untuk mengetahui apakah terdapat hubungan yang signifikan antara sikap inovatif petani dan produktivitas usahatani padi sawah.

e. Untuk mengetahui apakah ada faktor-faktor lain yang memiliki hubungan signifikan dengan produktivitas usahatani padi sawah di Kecamatan Tunpaan?

Adapun manfaat penelitian ini adalah:

a. Dapat memberikan informasi bagi petugas penyuluh pertanian dalam menyusun dan mengembangkan strategi penyuluhan pertanian;

b. Bermanfaat bagi pengembangan ilmu pengetahuan, khususnya ilmu komunikasi dan penyuluhan pertanian.

\section{METODOLOGI PENELITIAN}

\section{Metode Pengumpulan Data}

Dalam penelitian ini metode yang digunakan adalah survei. Data yang dikumpulkan terdiri dari data primer dan data sekunder. Data primer diperoleh dari hasil wawancara langsung menggunakan Instrumen Penelitian berupa Angket, yang terdiri dari 3 bagian, yaitu instrumen pengumpul data etos kerja, instrumen pengumpul data motivasi keberhsilan, dan instrumen pengumpul data sikap inovatif. Data sekunder diperoleh dari instansi-instansi yang terkait.

\section{Metode Pengambilan Sampel}

Penentuan lokasi (Desa) sampel dilakukan secara sengaja yaitu tiga desa yang memiliki areal sawah yang luas di Kecamatan Tumpaan. Adapun sampel yang dijadikan responden dari penelitian ini diambil secara acak sederhana (Simple Random Sampling) dari populasi petani padi sawah di tiga desa tersebut. Jumlah sampel yang diambil 10 petani padi sawah di setiap desa terpilih, sehingga jumlah sampel penelitian ini sebanyak 30 petani padi sawah.

\section{Variabel dan Konsep Pengukuran}

Variabel-variabel yang diukur pada penelitian ini terdiri dari 4 variabel yaitu: Produktivitas padi sawah, etos kerja petani, motivasi keberhasilan petani, dan sikap inovatif petani.

\section{a. Produktivitas padi sawah}

Produktivitas padi sawah merupakan perbandingan antara totalitas produuksi padi sawah dengan luas lahan yang akan diusahakan pada musim tanam terakhir, yang diukur dalam $\mathrm{kg} / \mathrm{ha}$ eq. Beras.

\section{b. Etos kerja petani}

Etos kerja petani adalah semangat dan mentalitas petani yang berwujud menjadi seperangkat perilaku kerja yang positif. Pengukurannya melalui penilaian petani sendiri terhadap beberapa "item" yang merujuk pada semangat dan mentalitas petani dalam bekerja dengan cara memberikan skor $1 \mathrm{~s} / \mathrm{d} 5$ pada setiap item, dimana :

- Skor 1 : sangat rendah

- Skor 2 : rendah

- $\quad$ Skor 3 : ragu-ragu

- Skor 4 : tinggi

- $\quad$ Skor 5 : sangat tinggi

\section{c. Motivasi kerja}

Motivasi yang dimaksud adalah dorongan yang ada dalam diri seseorang untuk melakukan perbuatan atau tingkahlaku dalam hubungan dengan pencapaian tujuan yang diharapkan. Pengukuran motivasi didasarkan atas tiga komponen yang membentuknya yaitu: motif, pengharapan (expectation), dan insentif.

Motif adalah dorongan yang ada dalam diri seseorang untuk melakukan kegiatan-kegiatan dalam rangka mencapai tujuan. Dorongandorongan tersebut berupa alasan-alasan yang menjadi dasar seseorang melakukan sesuatu.

Pengharapan (expectation) merupakan keyakinan terhadap keberhasilan yang dicapai 
melalui kegiatan-kegiatan yang dilakukan. Pengharapan dapat diukur melalui hal-hal yang menyangkut keyakinan akan keberhasilan dari usahanya, harapan akan adanya jaminan masa depan, harapan akan jaminan kesejahteraan, harapan akan adanya perlindungan pemerintah.

Insentif merupakan perangsang atau daya tarik yang sengaja diberikan kepada seseorang agar dapat berperilaku sesuai yang diharapkan. Pengukurannya didasarkan atas hal-hal yang memberikan daya tarik seperti adanya jaminan pemasaran produk yang dihasilkan, adanya bantuan permodalan, tersedianya fasilitas produksi yang memadai adanya kebijakan pemerintah yang berpihak kepada petani.

Pengukuran variabel motivasi adalah seberapa besar dorongan, harapan dan insentif yang diraakan petani dalam hubungan dengan kegiatan usahataninya. Besarnya motivasi diukur melalui pemberian skor $1 \mathrm{~s} / \mathrm{d} 5$ terhadap item-item yang merujuk pada ketiga aspek motivasi tersebut (motif, harapan dan insentif), dimana :

- Skor 1 : sangat rendah

- Skor 2 : rendah

- Skor 3 : ragu-ragu

- $\quad$ Skor 4 : tinggi

- Skor 5 : sangat tinggi

\section{d. Sikap Inovatif}

Sikap inovatif adalah derajat kesetujuan seseorang terhadap sesuatu inovasi sebagai obyek yang disikapi (given object). Untuk mengukur derajat kepositifan seseorang terhadap ionovasi disusunlah seperangkat pernyataan (item) yang berhubungan dengan kemanfaatan dari inovasi tersebut. Pengukuran sikap menggunakan metode Likert's Summated Ratings (LSR) dengan skala yang terdiri dari 5 tingkatan (skor 1 s/d skor 5) (Riduwan 2002). Untuk item-item positif nilai skor berlaku seperti berikut ini:

- $\quad$ Skor 1 sangat tidak setuju

- Skor 2 tidak setuju

- Skor 3 ragu-ragu

- Skor 4 setuju

- Skor 5 sangat setuju
Sedangkan untuk item-item negatif nilai skor sebaliknya, yaitu:

- Skor 1 sangat setuju

- Skor 2 setuju

- Skor 3 ragu-ragu

- Skor 4 tidak setuju

- Skor 5 sangat tidak setuju

\section{Analisis Data}

Analisis yang digunakan dalam penelitian ini terdiri dari:

a. Analisis deskriptif, yaitu untuk menggambarkan keadaan aktual dari setiap variabel penelitian; dan

b. Analisis korelasi dari Pearson (Pearson's correlation) yang digunakan untuk mengetahui ada-tidaknya hubungan yang signifikan antara etos kerja, motivasi kerja dan sikap inovatif dengan produktivitas padi sawah,

Adapun rumus korelasi yang akan digunakan mengikuti formula yang dikemukakan oleh Daniel (2001) :

$$
\mathbf{R}_{\mathrm{xy}}=\frac{\sum \mathbf{x}_{\mathrm{i}} \mathbf{y}_{\mathbf{i}}}{\sqrt{\left(\sum \mathbf{x}_{\mathbf{i}}^{2}\right)\left(\sum \mathbf{y}_{\mathbf{i}}{ }^{2}\right)}}
$$

Di mana:

$\mathrm{R}$ adalah koefisien korelasi

$\mathrm{x}$ adalah variabel etos kerja/ motivasi/ sikap inovatif

y adalah variabel produktivitas usahatani padi sawah

Nilai $\mathrm{R}$ di uji tingkat signifikansi pada $\alpha$ $=0,1$. Jika nilai $t_{\text {hitung }}>t_{\text {tabel }}$ maka terdapat hubungan yang signifikan antara variabel-variabel yang di korelasikan dan sebaliknya, jika nilai $\mathrm{t}_{\text {hitung }}<\mathrm{t}_{\text {tabel }}$ maka tidak terdapat hubungan yang signifikan antara variabel-variabel yang di korelasikan. 


\section{Pelaksanaan Kegiatan}

Penelitian ini dilaksanakan selama tiga bulan yaitu bulan Mei 2010 sampai dengan buan Juli 2010, mulai dengan persiapan, pengumpulan data, sampai penyusunan laporan penelitian. Tempat penelitian dilakukan di Kecamatan Tumpaan Kabupaten Minahasa Selatan.

\section{HASIL PENELITIAN DAN PEMBAHASAN}

\section{Deskripsi Faktor-Faktor Psikologis}

Dalam penelitian ini faktor-faktor psikologis yang diteliti adalah (1) etos kerja petani, (2) motivasi berprestasi (achievement motivation), dan sikap inovatif petani. Hasil penelitian ini pertama-tama mendeskripsikan keberadaan (eksistensi) dari ketiga faktor psikologis tersebut kemudian selanjutnya menganalisis keterkaitannya dengan kinerja petani dalam mengembangkan usahatani padi sawah, dalam hal ini produktivitas usahatani).

Secara operasional ketiga faktor (variabel) psikologis tersebut diukur melalui penilaian sendiri (self evaluation) oleh petani responden terhadap seperangkat item yang merujuk pada indikator masing-masing faktor psikologis tersebut. Hasil pengukuran diberikan dalam 5 skala (skor) yang menunjukkan derajat dari masing-masing faktor, yaitu :

- Skor 1 : sangat rendah/sangat tidak setuju

- Skor 2 : rendah/tidak setuju

- Skor 3 : netral/sedang/cukup

- Skor 4 : tinggi/setuju

- Skor 5 : sangat tinggi/sangat setuju

Untuk mendeskripsikan ketiga variabel psikologis tersebut dilakukan dalam dua cara, yaitu: pertama secara kumulatif, yaitu dengan menghitung secara relatif total skor yang diperoleh semua responden terhadap total yang seharusnya dari setiap variabel psikologis. Perhitungannya mengikuti konsep yang dikemukakan oleh Riduwan, 2002, seperti berikut ini :
- $\quad \mathrm{SR}=1 \times \sum \mathrm{I} \times \sum \mathrm{R}$

- $\quad \mathrm{ST}=5 \times \sum \mathrm{I} \times \sum \mathrm{R}$

- Derajat/Tingkat dari setiap variabel dihitung sebagai berikut: (TS : ST) x $100 \%$

(Dimana: $\mathrm{SR}=$ Skor Terendah; $\mathrm{ST}=\mathrm{Skor}$ Tertinggi; $\sum \mathrm{I}=$ jumlah Item alat ukur; $\sum \mathrm{R}$ $=$ jumlah Responden; $1=$ skala terendah dari setiap Item alat ukur; dan $5=$ skala tertinggi dari setiap Item alat ukur, dan TS $=$ Total Skor yang diperoleh responden).

Atau, dapat dengan secara langsung melihat letak total skor yang diperoleh semua responden pada skala kategori (0 s/d 100\%). Kedua, dengan cara menghitung frekuensi sebaran normatif, dengan cara sebagai berikut: Jika, SR adalah skor terendah yang diperoleh responden; ST adalah skor tertinggi yang diperoleh responden; L adalah lebar kelas $=(\mathrm{ST}-\mathrm{SR}) / \mathrm{K}$ dan $\mathrm{K}$ adalah banyaknya kelas, maka :

- Kelas/kategori I = SR + L;

- Kelas/Kategori II = batas atas kelas I+L;

- Kelas/Kategori III = batas atas kelas II + L;

- Kelas/Kategori IV = batas atas kelas III + L;

- Kelas/kategori $\mathrm{V}=$ batas atas kelas IV + L

\section{Etos Kerja Petani}

Etos kerja petani adalah semangat dan mentalitas petani yang berwujud menjadi seperangkat perilaku kerja yang positif. Hasil penelitian menunjukkan skor terendah (SR) yang diperoleh petani responden sebesar 450 (1x15x30), sementara skor tertinggi (ST) yang diperolah petani responden sebesar 2250 (5x15x30). Dengan demikian derajat Etos Kerja Petani adalah total skor (TS) dari semua responden (1787) dibagi dengan skor tertinggi (ST) dari semua item alat ukur (2250) dikalikan dengan 100 persen, maka diperoleh: (1787/2250) $\mathrm{x} 100 \%=79,42$ persen. Angka ini terteltak pada skala kriteria 'tinggi'. Dengan demikian, etos kerja petani padi sawah di Kecamatan Tumpaan tegolong 'tinggi'. Secara skematis dapat dilihat pada Gambar 1. 
Kriteria menurut Persentase:

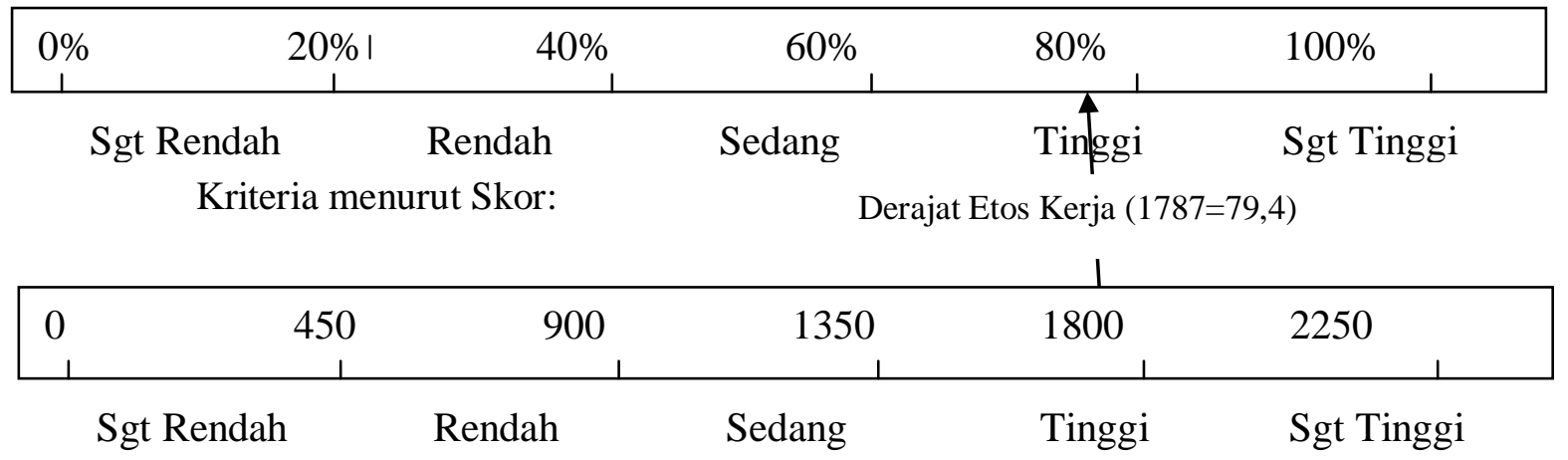

Gambar 1. Posisi Derajat Etos Kerja Petani dalam Skala Persentase dan Nilai Skor

Berdasarkan tabel frekuensi, maka dapat dikemukakan bahwa 50 persen responden telah memiliki etos kerja yang tinggi sampai sangat tinggi, sedangkan responden yang memiliki etos kerja "rendah' dan 'sangat rendah' hanya sekitar 23 persen.

Tabel 2. Jumlah dan Persentase Responden Menurut Derajat Etos Kerja

\begin{tabular}{lcc}
\hline \multicolumn{1}{c}{ Derajat Etos Kerja } & $\begin{array}{c}\text { Jumlah } \\
\text { Resp. } \\
\text { (org) }\end{array}$ & Persentase \\
\hline Sangat Rendah (40-46) & 2 & 6.67 \\
Rendah (47-53) & 5 & 16.67 \\
Netral (54-60) & 8 & 26.67 \\
Tinggi (61-67) & 10 & 33.33 \\
Sangat Tinggi 68+) & 5 & 16.67 \\
\hline Jumlah & 30 & 100 \\
\hline
\end{tabular}

\section{Motivasi Berprestasi (Achievement Motivation)}

Secara teori, motivasi berprestasi dibentuk oleh tiga komponen, yaitu: motif, pengharapan (expectation), dan insentif. Pengukuran variabel motivasi dikembangkan dari 3 komponen tersebut melalui pengembangan suatu instrumen (alat ukur) penelitian yang terdiri dari 16 item yang merujuk pada indikator-indikator motivasi kerja (motivasi berprestasi). Hasil penelitian menunjukkan bahwa :

$$
\begin{aligned}
& \mathrm{SR}=1 \times 16 \times 30=480 ; \\
& \mathrm{ST}=5 \times 16 \times 30=2400
\end{aligned}
$$

TS = 1706 (total skor kumulatif yang diperoleh dari 30 responden)

Dengan demikian motivasi berprestasi dari petani responden adalah (TS/ST) $\times 100 \%=$ $(1706 / 2400) \times 100 \%=71,1$ persen. Angka ini berada pada skala persentase yang 'tinggi'. Hasil penelitian dapat digambarkan sebagai berikut (Gambar 3). Dilihat dari frekuensi sebaran jumlah responden menurut skala motivasi maka dapat dijelaskan bahwa perolehan skor oleh petani responden berkisar antara $49 \mathrm{~s} / \mathrm{d} 71$. 


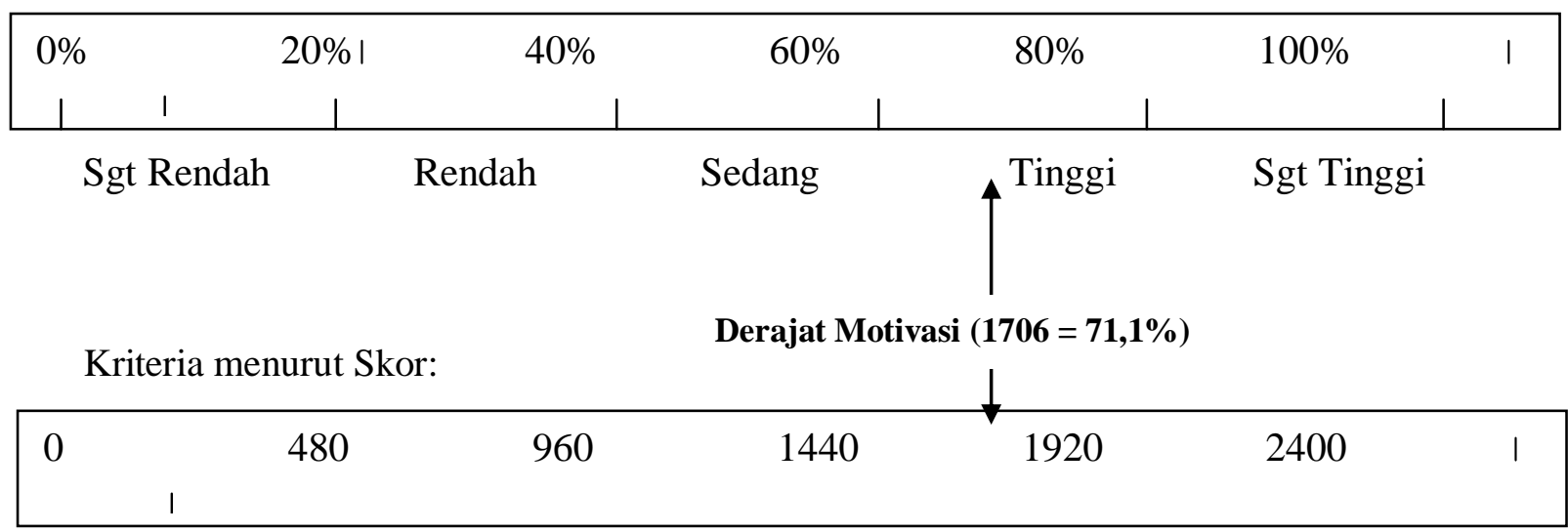

| Sgt Rendah | Rendah | Sedang | Tinggi | Sgt Tinggi |

Gambar 2. Posisi Derajat Motivasi Berprestasi Petani dalam Skala Persentase dan Nilai Skor

Berdasarkan sebaran data tersebut motivasi berprestasi dikategorikan kedalam 5 kelas dan hasilnya diperoleh 43,3 persen responden memiliki motivasi yang "tinggi" dan "sangat tinggi" (Tabel 3).

Tabel 3. Jumlah dan Persentase Responden menurut Derajat Motivasi

\begin{tabular}{lccc}
\hline Derajat Motivasi & $\begin{array}{c}\text { Jumlah } \\
\text { (Org) }\end{array}$ & Persentase & S \\
\hline Sgt Rendah (49-53) & 4 & 13,33 & P3 \\
Rendah (54-57) & 8 & 26,67 & dik \\
Sedang (58-61) & 5 & 16.67 \\
Tinggi (62-65) & 9 & 30,00 \\
Sgt Tinggi (66-71) & 4 & 13,33 \\
\hline Jumlah & 30 & 100 \\
\hline
\end{tabular}

\section{Sikap Inovatif}

Sikap inovatif adalah derajat kesetujuan seseorang terhadap sesuatu inovasi sebagai obyek yang disikapi (given object). Untuk mengukur derajat sikap inovatif petani dilakukan dengan meggunakan instrumen pengukuran sikap yang terdiri dari 21 item. Setiap item merupakan pernyataan yang berhubungan dengan inovasi dan disikapi oleh petani responden dalam 5 skala, yaitu: sangat tidak setuju; setuju; tidak memberikan respon (netral); setuju; dan sangat setuju. Untuk item pernyataan positif diberi skor 1 untuk sangat tidak setuju dan skor 5 untuk sangat setuju. Sebaliknya, untuk item pernyataan negatif diberi skor 1 untuk sangat setuju dan skor 5 untuk sangat tidak setuju. Dengan cara perhitungan seperti yang dilakukan sebelumnya, diketahui bahwa:

- $\quad \mathrm{SR}=1 \times 21 \times 30=630$

- $\quad \mathrm{ST}=5 \times 21 \times 30=3150$

Total Skor yang diperoleh keseluruhan responden $(\mathrm{TS})=2407$

Maka derajat sikap petani responden adalah: $(2407 / 3150) \times 100=76,41 \%$. Perolehan nilai skor dari semua responden menunjukkan bahwa sikap inovatif petani responden berada dalam kategori 'tinggi' (Gambar 3) 
Kriteria menurut Skala Persentase:

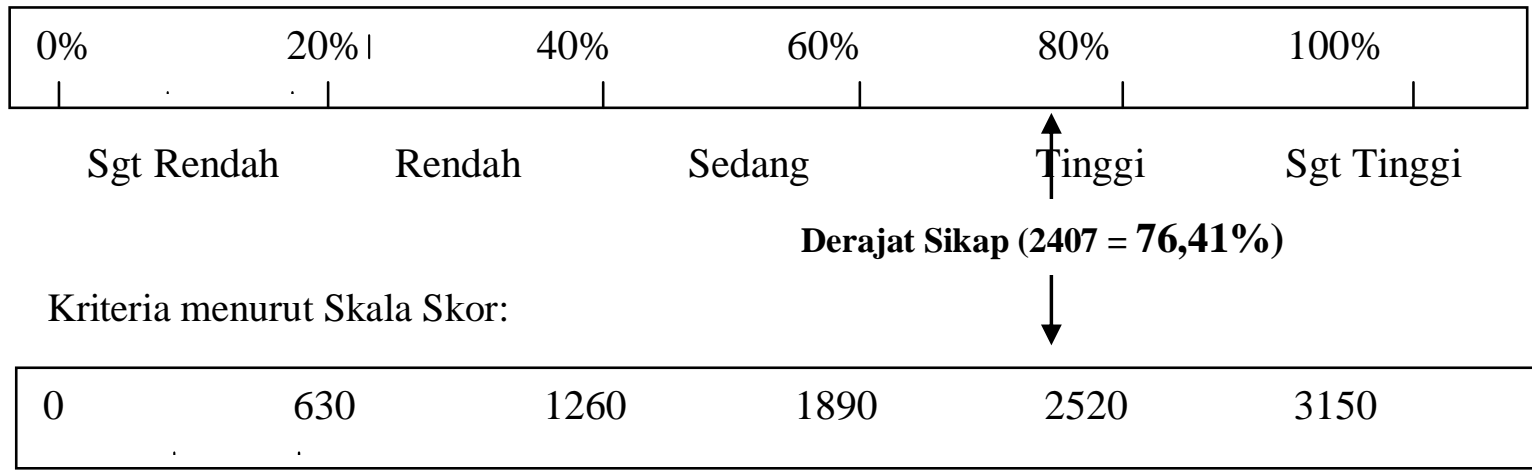

Sgt Rendah ' Rendah ' Sedang I $\quad$ Tinggi I $\quad$ Sgt Tinggi

Gambar 3. Posisi Derajat Sikap Inovatif Petani dalam Skala Persentase dan Nilai Skor

Berdasarkan perolehan skor masing-masing responden, maka skor terendah adalah 49 dan skor tertinggi 71 . Jika dikategorikan dalam 5 skala maka sebagian besar responden $(36,67 \%)$ memiliki motivasi "tinggi" dan 20 persen memiliki motivasi "sangat tinggi" (Tabel 4). Dari hasil analisis data ketiga variabel psikologis tersebut maka dapat disimpulkan bahwa ketiga variabel tersebut tergolong tinggi (menurut 5 skala yang ditetapkan).

Tabel 4. Jumlah dan Persentase Responden menurut Derajat Motivasi

\begin{tabular}{lcc}
\hline \multicolumn{1}{c}{ Derajat Motivasi } & Jumlah (Org) & Persentase \\
\hline Sgt. Rendah (49-53) & 4 & 13.33 \\
Rendah (54-57) & 5 & 16.67 \\
Menengah (58-61) & 4 & 13.33 \\
Tinggi (62-65) & 11 & 36.67 \\
Sgt. Tinggi (66-71) & 6 & 20.00 \\
\hline Jumlah & 30 & 100 \\
\hline
\end{tabular}

Tabel 5. Rekapitulasi Derajat Ketiga Faktor Psikologi

\begin{tabular}{llllll}
\hline Faktor Psikologis & SR & ST & TS & $\%$ & Derajat \\
\hline Etos Kerja & 450 & 2250 & 1787 & 79,4 & Tinggi \\
Motivasi Berprestasi & 480 & 2400 & 1706 & 71,1 & Tinggi \\
Sikap Inovatif & 630 & 3150 & 2407 & 76,41 & Tinggi \\
\hline
\end{tabular}

Keterangan:

- $\quad$ SR = Skor Terendah dari semua Item Instrumen Pengumpul Data

- $\quad$ ST $=$ Skor Tertinggi dari semua Item Instrumen Pengumpul Data

- $\quad$ TS = Total Skor yang diperoleh semua responden dari hasil penelitian 


\section{Kinerja Petani (Produktivitas Usahatani)}

Kinerja petani diukur dari produktivitas usahatani yang dikembangkannya, yaitu usahatani padi sawah. Besarnya produktivitas diukur dari perbandingan antara total produksi padi sawah yang dihasilkan dengan luas tanam padi sawah. Karena kebanyakan petani menjual produknya dalam bentuk beras maka produktivitas padi sawah diukur dalam equivalen beras.

Hasil penelitian menunjukkan bahwa poduktivitas padi sawah di tingkat petani bervariasi antara 1.163,64 sampai dengan $3.030,30 \mathrm{~kg} / \mathrm{ha}$ dengan rata-rata $2.042,30 \mathrm{~kg} / \mathrm{ha}$ setara beras. Jika dikonversi ke dalam gabah kering giling (GKG), dimana rendemen 1:0,6 maka produktivitas rata-rata di tingkat petani responden sebesar 34,04 kw/ha. Jika dibandingkan dengan angka produktivitas padi sawah di tingkat nasional maupun di tingkat Provinsi Sulawesi Utara, maka angka produktivitas rata-rata di tingkat petani sampel masih jauh lebih kecil. Untuk jelasnya dapat dilihat perbandingan angka produktivitas padi sawah dalam satuan gabah kering giling (GKG) seperti pada Tabel 6 .

Tabel 6. Luas Panen, Produksi dan Produktivitas Padi Sawah Di Beberapa Daerah dan Petani Sampel

\begin{tabular}{|c|c|c|c|}
\hline Daerah & $\begin{array}{l}\text { Luas } \\
\text { Panen }\end{array}$ & $\begin{array}{l}\text { Produksi } \\
\text { (Ton) }\end{array}$ & $\begin{array}{c}\text { Produktivitas } \\
(\mathrm{Kw} / \mathrm{Ha})\end{array}$ \\
\hline Nasional $^{1)}$ & - & - & 44,00 \\
\hline Prov. Sulut ${ }^{2)}$ & 94.523 & 473.940 & 50,14 \\
\hline Kab. Minsel ${ }^{2)}$ & 16.346 & 63.959 & 39,13 \\
\hline Kec. Tumpaan ${ }^{3)}$ & 771 & $3.704,7$ & 48,10 \\
\hline Rata2 Sampel ${ }^{4)}$ & - & - & 34,04 \\
\hline
\end{tabular}

Sumber: ${ }^{1)}$ Vitriani, Vina (2009); ${ }^{2)}$ BPS Sulut (2008);

${ }^{3)}$ BPS Minsel (2008) ${ }^{4)}$ Petani Sampel

Selanjutnya, jika sebaran angka produktivitas padi sawah di tingkat petani sampel dikelompokkan ke dalam kelas tingkat produktivitas (dalam satuan eq. Beras) maka dapat dilihat seperti pada Tabel 7 berikut ini. Berdasarkan tabel frekuensi maka dapat dilihat bahwa sebagaian besar $(21 \%)$ petani responden angka produktivitas usahatani padi sawah berada di antara 1.786 s/d 2.408 kilogran per hektar setara beras. Sedangkan produktivitas di atas $2.408 \mathrm{~kg} / \mathrm{ha}$ hanya 13 persen dan masih cukup banyak petani $(16,67 \%)$ yang produktivitasnya di bawah $1.786 \mathrm{~kg} / \mathrm{ha}$.

Tabel 7. Jumlah dan Persentase Responden menurut Produktivitas Usahatani Padi Sawah di Kecamatan Tumpaan

\begin{tabular}{ccc}
\hline $\begin{array}{c}\text { Produktivitas } \\
(\mathrm{Kg} / \mathrm{Ha})^{*)}\end{array}$ & $\begin{array}{c}\text { Jumlah } \\
(\mathrm{Org})\end{array}$ & Persentase \\
\hline $1164-1786.0$ & 5 & 16.67 \\
$1786.1-2408.0$ & 21 & 70.00 \\
$>2408$ & 4 & 13.33 \\
\hline Jumlah & 30 & 100 \\
\hline
\end{tabular}

$\sqrt[*]{\text { Equivalen beras }}$

\section{Analisis Hubungan}

Sebagaimana yang menjadi salah satu tujuan penelitian ini, yaitu mencari hubungan antara variabel-variabel psikologis dengan kinerja usahatani yang dalam hal ini adalah besarnya produktivitas usahatani padi sawah, maka pada bagian ini akan dikemukakan hasil analisis hubungan antar variabel-variabel tersebut. Metode analisis yang digunakan adalah analisis korelasi product moment dari Pearson (Pearson's Correlation). Dengan bantuan program "Minitab" makadapat diketahui besaran koefisien korelasi antar variabel yang dianalisis.

\section{Etos Kerja dan Produktivitas Usahatani Padi Sawah}

Berdasarkan hasil analisis korelasi Pearson (Pearson's Correlation) maka antara variabel Etos Kerja dan variabel Produktivitas memiliki hubungan yang sangat signifikan $(r=0,67$; $\mathrm{p}=0,00$ ). Artinya makin tinggi etos kerja petani, maka makin tinggi produktivitas usahatani padi sawah. Hal ini sesuai dengan pernyataan Tasmara dalam Iskandar (2002), etos kerja yang tinggi mempunyai makna bersungguh-sungguh menggerakkan seluruh potensi dirinya untuk mencapai sesuatu, dan juga orang yang mempunyai etos kerja tinggi sangat menghargai waktu, tidak pernah merasa puas, berhemat dan memiliki semangat kerja yang tinggi. 
Adanya hubungan yang berarti antara etos kerja dan produktivitas memberi pengertian bahwa etos kerja merupakan variabel yang penting untuk diperhatikan dalam menjelaskan veriabel produktivitas petani dalam menggarap lahan pertanian. Banyak cara yang dapat diterapkan untuk mengembangkan dan meningkatkan etos kerja, karena etos kerja adalah sikap mendasar terhadap diri, serta merupakan aspek evaluatif yang bersifat menilai (Morgan 1961), diantaranya adalah membangkitkan kesadaran, agar etos kerja petani meningkat sehingga akan meningkatkan pendapatan dan mensejah-terakan kehidupan petani.

\section{Motivasi dan Produktivitas Usahatani Padi Sawah}

Hasil analisis menunjukkan bahwa anatara variabel motivasi berprestasi dan produktivitas usahatani tidak terdapat hubungan yang berarti. Hal ini dapat diliht dari besarnya koefisien korelsi $(r=0,21 ; p=0,27)$. Secara teoritis motivasi banyak dipengaruhi oleh emosi. Seseorang yang memilki kecerdasan emosional akan mengarahkan emosinya menjadi motivasi yang mengarah kepada keberhasilan prestasi kerjanya. Motivasi dapat juga disebut sebagai dorongan, hasrat atau kebutuhan manusia dalam melakukan kegiatan tertentu (Rogers 1971).

Tabel 8. Koefisien Korelasi dari Pearson dan Derajat Signifikansi Antar Beberapa Variabel Penelitian

$\begin{array}{llllllll}\mathrm{X} 1 & \mathrm{X} 2 & \mathrm{X} 3 & \mathrm{Y} & \mathrm{X} 4 & \mathrm{X} 5 & \mathrm{X} 6 & \mathrm{X} 7 \\ \mathrm{X} 2 & 0.377 & & & & & & \\ & 0.040 & & & & & & \\ \mathrm{X} 3 & 0.461 & 0.143 & & & & & \\ & 0.010 & 0.451 & & & & & \\ \mathrm{Y} & 0.668 & 0.206 & 0.696 & & & & \\ & 0.000 & 0.274 & 0.000 & & & & \\ \mathrm{X} 4 & 0.064 & -0.141 & 0.033 & -0.082 & & & \\ & 0.738 & 0.458 & 0.861 & 0.666 & & & \\ \mathrm{X} 5 & -0.001 & -0.021 & 0.099 & 0.348 & -0.416 & & \\ & 0.997 & 0.912 & 0.604 & 0.060 & 0.022 & & \\ \mathrm{X} 6 & 0.062 & -0.072 & 0.040 & -0.162 & 0.632 & -0.486 & \\ & 0.743 & 0.706 & 0.835 & 0.393 & 0.000 & 0.006 & \\ \mathrm{X} 7 & -0.216 & -0.032 & -0.045 & -0.030 & -0.170 & 0.233 & -0.439 \\ & 0.251 & 0.867 & 0.813 & 0.875 & 0.369 & 0.215 & 0.015\end{array}$

Cell Contents: Pearson correlation P-Value
Keterangan:

$\mathrm{X} 1$ = Variabel Etos Kerja

$\mathrm{X} 2=$ Variabel Motivasi Berprestsi

$\mathrm{X} 3=$ Variabel Sikap Inovatif

$\mathrm{X} 4=$ Umur (thn)

$\mathrm{X} 5=$ Tingkat Pendidikan

$\mathrm{X} 6=$ Pengalaman berusahatani (thn)

X7 = Jumlah tanggungan keluarga (org)

$\mathrm{Y}=$ Produktivitas usahatani padi sawah (kg/ha eq. beras)

Tidak adanya hubungan yang signifikan antara motivasi dan produktivitas dapat dijelaskan bahwa petani dalam meningkatkan produktivitas usahanya bukan didorong oleh kecerdasan emosionalnya tetapi lebih banyak didorong oleh karena adanya keharusan (tidak ada pilihan lain) dalam mengembangkan usahatani padi sawah. Sehingga besar kecilnya produktivitas tidak ditentukan oleh tinggi rendahnya motivasi petani.

\section{Sikap Inovatif dan Produktivitas Usahatani Padi Sawah}

Sikap inovatif merupakan salah satu unsur kepribadian yang dimiliki seseorang dalam menentukan tindakan dan bertingkah laku terhadap suatu obyek disertai dengan perasaan positif dan negatif. Sikap inovatif mempunyai hubungan positif yang sangat signifikan dengan produktivitas petani $(\mathrm{r}=0,696 ; \mathrm{p}=0,00)$. Oleh sebab itu variabel sikap inovatif petani merupakan variabel penting untuk diperhatikan, karena sikap sebagai suatu sistem yang memiliki tiga komponen yang saling tergantung yakni kognisi, afeksi dan konasi (Simanjuntak, 1995). Kognisi menyangkut keyakinan terhadap obyek sikap, afeksi menyangkut perasaan dan konasi menyangkut kecenderungan untuk berbuat (Suriasumantri 1989). Sedang menurut Gagne (1985), sikap adalah predisposisi untuk merespon, tetapi berbeda dengan kecenderungan terhadap suatu respon evaluasi, seseorang cenderung untuk memilih tindakan dalam rangka meningkatkan rasa senang terhadap obyek tertentu.

\section{Hubungan antar Variabel Psikologis}

Hasil analisis korelasi antar bariabelvariabel psikologis: etos kerja, motivasi berprestasi dan sikap inovatif, menunjukkan bahwa yang memiliki hubungan signifikan adalah 
antara variabel etos kerja dan motivasi berprestasi $(\mathrm{r}=0,38 ; \mathrm{p}=0,04)$ dan antara variabel etos kerja dan variabel sikap inovatif $(\mathrm{r}=0,46 ; \mathrm{p}=0,01)$. Sementara antara variabel motivasi dan variabel sikap inovatif tidak menunjukkan adanya hubungan yang berarti. Hal ini menjelaskan bahwa variabel etos kerja memiliki hubungan yang luas sehingga keberadaannya sebagai variabel psikologis begitu penting dan utama dalam meningkatkan kinerja usahatani.

\section{Hubungan antara Variabel-Variabel Karakteristik Petani dan Variabel- Variabel Psikologis}

Ternyata dari hasil analisis korelasi tidak ada satupun variabel karakteristik petani yang memiliki hubungan yang signifikan dengan variabel-variabel psikologis (etos kerja, motivasi berprestasi dan sikap inovatif). Hal ini berarti bahwa tinggi rendahnya etos kerja, motivasi berprestasi dan sikap inovatif petani tidak ada hubungannya dengan karakteristik petani (umur (X4), Tingkat Pendidikan (X5), Pengalaman berusahatani (X6), dan jumlah tanggungan keluarga (X7).

\section{Hubungan antara Variabel Karakteristik Petani dan Produktivitas}

Variabel-variabel karakteristik petani yang diteliti adalah umur (X4), Tingkat Pendidikan (X5), Pengalaman berusahatani (X6), dan jumlah tanggungan keluarga (X7). Setelah dikorelasikan dengan variabel produktivitas usahatani padi sawah maka hanya variabel tingkat pendidikan yang berhubungan signifikan dengan variabel produktivitas usahatani $(\mathrm{r}=0,35 ; \mathrm{p}=0,06)$. Hal ini dapat menjelaskan bahwa petani yang berpendidikan formal yang tinggi cenderung memiliki produktivitas usahatani yang tinggi pula. Sementara variabel-vriabel karakteristik lainnya tidak menunjukkan adanya hubungan yang berarti.

\section{KESIMPULAN DAN SARAN}

\section{Kesimpulan}

(1) Ketiga variabel psikologis yang diteliti (etos kerja, motivasi berprestasi dan sikap inovatif tergolong dalam kategori "tinggi" (dalam lima skala kategori) pada petani padi sawah di Kecamatan Tumpaan

(2) Produktivitas padi sawah sebagai wujud kinerja petani dalam mengelola usahatani padi sawah bervariasi antara 1.163,64 sampai dengan 3.030,30 $\mathrm{kg} / \mathrm{ha}$ dengan rata-rata $2.042,30 \mathrm{~kg} / \mathrm{ha}$ setara beras atau 34,04 kw/ha GKG.

(3) Variabel-variabel psikologis yang memiliki hubungan positif yang signifikan dengan kinerja usahatani padi sawah adalah variabel etos kerja dan variabel sikap inovatif. Sedangkan variabel motivasi tidak nyata hubungannya dengan variabel kinerja usahatani padi sawah. Artinya, variabel etos kerja dan variabel sikap inovatif dapat menjelaskan besar kecilnya produktivitas usahatani padi sawah di Kecamatan Tumpaan.

(4) Variabel etos kerja memiliki peran penting karena memiliki hubungan yang luas dengan variabel psikologis lainnya, yaitu dengan variabel motivasi dan variabel sikap inovatif

(5) Variabel-variabel karkteristik petani tidak ada kaitan sama sekali dengan variabel-variabel psikologis, artinya tinggi fendahnya etos kerja, motivasi berprestasi dan sikap inovatif petani tidak tergantung pada variabel-variabel karakteristik petani.

(6) Dari semua variabel karakteristik petani, hanya variabel tingkat pendidikan formal petani yang berhubungan positif dengan produktivitas usahatani. Hal ini menunjukkan bahwa tingkat pendidikan formal masih berperan penting dalam mewujudkan kinerja bagi petani. 


\section{Saran}

(1) Jika selama ini penyuluhan pertanian lebih diarahkan pada aspek fisik-teknis (hard skill) saja, maka sekarang dianjurkan agar bersamaan dengan spek teknis tersebut aspek non-teknis (soft skill) juga termasuk etos kerja, motivasi dan sikap inovatif) perlu mendapat perhatian dalam pelaksanaan penyuluhan bagi para petani.

(2) Perlu adanya penelitian lanjutan yang sama yang dilakukan lebih komprehensif lagi pada cakupan wilayah dan populasi yang lebih besar, guna mendapatkan pembuktian yang lebih valid bahwa aspek psikologis itu sangat penting bagi petani dalam upaya meningkatkan kinerja usahanya.

\section{DAFTAR PUSTAKA}

Anonimous, 2009. Sulawesi Utara Dalam Angka, BPS Sulut Manado

Anonimous, 2009. Kabupaten Minahasa Selatan Dalam Angka, BPS Minsel 2009.

Daniel, Moehtar, 2001. Metode Penelitian Sosial Ekonomi, Bumi Aksara, Jakarta.

Fitriani, Vina, 2009. Era Bercocok Tanam Padi Sawah, http://nirhono.wordpress.com/ 2009/06/28/era-bercocok-tanam-padisawah/

Iskandar, Otto, 2002, Etos Kerja, Motivasi, dan sikap Inovatif Terhadap Produktivits Petani. Jurnal Makara, Sosial Humaniora Vol.6 No.1, Juni 2002.

Kerlinger Fred dan E. J. Pedhazur,1987. Korelasi dan Analisis Regresi Ganda, Nur Cahaya.

Mardikanto. T. S dan S. Sutarni, 1992. Pengantar Penyuluhan Pertanian, Surakarta.

Margono S, 1978. Kumpulan Bacaan Penyuluhan Pertanian. Institut Pertanian Bogor.

Maslow, Abraham H. 1954. Motivation and Personality. New York: Harver \& Raw Publisher.
Morgan, T. Clifford. 1961. Introduction to Psychology. New York: Mc Graw Hill Book Company Inc.

Nur Cahaya, 1987. Pengaruh Motivasi, Kepemimpinan, Komunikasi dan Kondisi Fisik Tempat Kerja terhadap Semangat Kerja Pegawai dalam Kerlinger \& Pedhazur: Korelasi dan Analisis Regresi Berganda, UGM Yogyakarta

Riduwan, 2002. Skala Pengukuran VariabelVariabel Penelitian, Alfabeta Bandung

Rafael L, 1996. Komunikasi Penyuluhan Pertanian. PT. Citra Aditya Bakti, Bandung.

Rogers, E.M dan Flloyd Shoemaker, 1971. Communication of Innovation: A Cross Cultural Approach, McGraw-Hill New York

Siahaan. S. M, 1991. Komunikasi, Pemahaman dan Penerapannya. PT. BPK Gunung Mulia, Jakarta.

Simanjuntak, P. J. (ed). 1995. Peningkatan Produktivitas dan Mutu Pelayanan Sektor Pemerintah. Jakarta: Dewan Produktivitas Nasional.

Sinamo, Jansen, 2009. Etos Kerja. http://dekill.blogspot.com/2009/01/etos-kerja.html

Suprapto T dan Fahrianoor, 2004. Komunikasi Penyuluhan. Arti Bumi Intaran, Yokyakarta.

Suriasumantri, Jujun S. 1989. Berpikir Sistem. Konsep, Penerapan Teknologi dan Strategi Implementasi. Jakarta: FPS IKIP Jakarta.

Suriatna S, 1988. Metode penyuluhan pertanian. PT. Mediyatama Sarana Perkasa, Jakarta.

Tampubolon, Biatna Dulbert, 2007, Analisis Faktor Gaya Kepemimpinan dan Faktor Etos Kerja Terhadap Kinerja Pegawai Pada Organisasi Yang Telah Menerapkan SNI 19-9001-2001. Jurnal Standardisasi Vol.9 No.3 2007.

Tri Gunarsih, Binawan Nur Tjahjono,(?). Pengaruh Motivasi Kerja Dan Budaya Organisasi Terhadap Kinerja Pegawai Dilingkungan Dinas Bina Marga Propinsi Jawa Tengah. 
Tuyuwale, John A., 2008. Dasar Penyuluhan Pertanian, Bahan Ajar Fakultas Pertanian Unsrat, Manado 